\title{
Staff Protection Against Civil and Criminal Action Under the Mental Health Act 1983
}

Bridgit Dimond, Barrister-at-Law and Reader in Law and Health Service Management, The Polytechnic of Wales, Pontypridd, Mid Glamorgan

In the 19th century doctors threatened to go on certification strike unless they were given a measure of legal immunity. Provision was accordingly made in the Lunacy Act 1890 and that provision was the ancestor of S.139 of the Mental Health Act 1983.

Section 139 provides that:

(1) No person shall be liable, whether on the ground of want or jurisdiction or on any other ground, to any civil or criminal proceedings to which he would have been liable apart from this section in respect of any act purporting to be done in pursuance to this Act or any regulations or rules made under this Act, or in, or in pursuance of anything done in, the discharge of functions conferred by any other enactment on the authority having jurisdiction under Part VII of this Act, unless the act was done in bad faith or without reasonable care.

(2) No civil proceedings shall be brought against any person in any court in respect of any such act without the leave of the High Court; and no criminal proceedings shall be brought against any person in any court in . respect of any such act except by or with the consent of the Director of Public Prosecutions.

(3) This section does not apply to proceedings for an offence under this Act, being proceedings which, under any other provision of this Act, can be instituted only by or with the consent of the Director of Public Prosecutions.

(4) This section does not apply to proceedings against the Secretary of State or against a health authority within the meaning of the National Health Service Act 1977.

The purpose of this article is to consider the background to this section and analyse the reasons for and against giving staff in psychiatric and mental handicap hospitals greater protection from legal action than is provided in other hospitals and health work.

The immediate predecessor of S.139 was S.141 of the Mental Health Act 1959. This provided protection not just to the staff but also to the Health Authority and Secretary of State. In addition it required a potential litigant to provide substantial grounds for his contention that the defendant had acted in bad faith and without reasonable care in order to obtain leave from the High Court to proceed with the action.

The 1978 White Paper recommended certain changes. Yet the initial Mental Health (Amendment) Bill kept S.141 unchanged in its entirety. This led to considerable debate in Parliament. Lord Wallace of Coslany introduced an Amendment (No. 72), repealing S.141. He later withdrew this amendment, having been convinced by Lord Hooson's argument in favour of more limited protection for staff.
Lord Elton spoke for the Government in stating that S.141 was an essential safeguard "to protect staff who were going carefully and conscientiously about their duties under the Act, often in very difficult circumstances, from the continual threat of litigation. We have to realise that for staff caring for the mentally disordered this threat can be a very real one. Patients may suffer from severe and persistent delusions which make them quite unreasonably antagonistic towards a member of the hospital staff. The problem is particularly severe in the case of detained patients. These patients are in hospital against their will and it is likely that they will harbour resentment towards the staff whose duty it is to prevent their leaving hospital, particularly until they have had the opportunity to understand what their presence in the hospital is all about.

It is not reasonable to expect staff to work in constant fear of malicious litigation."

In contrast Lord Hooson spoke of the lack of justification for S.141 as it stood. There were four to five applications made to a High Court judge in a year in respect of civil proceedings, such figures did not seem to suggest that that kind of safeguard was appropriate or necessary. On the criminal aspect, Lord Hooson suggested that a more appropriate form of protection would be to ensure that no prosecution can be brought, either privately or otherwise, without the consent of the Director of Public Prosecution.

This debate in the House of Lords was overshadowed by the fact that one patient had alleged that S.141 was in violation of the European Convention on Human Rights and that case was due to be heard in just over a week's time; the general view was that the case was likely to succeed and S.141 would thus have to be repealed or amended anyway.

The European Convention for the Protection of Human Rights and Fundamental Freedoms (to which the United Kingdom is a signatory) includes in its articles Article 5(1). Everyone has the right to liberty and security of person. No-one shall be deprived of his liberty save in the following cases and in accordance with a procedure prescribed by law. Article 5(4) states that everyone who is deprived of his liberty by arrest or detention shall be entitled to take proceedings by which the lawfulness of his detention shall be decided speedily by a court and his release ordered if the detention is not lawful.

Ashingdane, a Broadmoor patient, brought his case before the European Commission of Human Rights on the grounds that there was a breach of Article 5(1) and Article 5(4).

The facts were, briefly, that he had been convicted of offences of reckless driving and being in possession of fire- 
arms. He was placed under a hospital restriction order and transferred from an ordinary psychiatric hospital, Oakwood, to Broadmoor. Subsequently doctors recommended his return to Oakwood, but industrial action by trade union employees prevented his return. He took action in the English Courts but the Court of Appeal held that his action against the Department of Health and Social Security, Kent Area Health Authority and the Secretaries of the two branches of the Trade Union was barred by Section 141 (18 February, 1980).

The European Court of Human Rights did not in fact uphold his case. (European Law Review, 1985, 10, 373). Deprivation of his liberty on grounds of mental disorder was justified under Article 5(1)(e), and in the special circumstances of the case his continued detention at Broadmoor was unavoidable. His argument that $S .141$ barred him of a remedy under Article 5(4) was also rejected on grounds that he was not seeking to challenge the legality of his detention, but rather the place where he was detained. The European Court of Human Rights pointed out that Article 5(4) does not guarantee a right to judicial control of the legality of all aspects or details of the detention. It is concerned simply with the lawfulness of the deprivation of liberty itself.

In addition the court upheld the legality of S.141. It noted the restriction was intended to prevent those responsible for the care of mental patients from being unfairly harassed by litigation. It took the view that this restriction on $\mathrm{Mr}$ Ashingdane's right to repair the Courts did not go to the very essence of his right to litigate but merely controlled the scope of any claim in a way which was justifiable and which did not transgress the principle of proportionality.

As a result of the Parliamentary debates, S.141 was substantially amended and the present $S .139$ contains the following major changes:

(1) The patient does not have to establish substantial grounds to obtain leave of the High Court to proceed with his case.

(2) The consent of the Director of Public Prosecutions must be obtained before criminal proceedings can be brought.

(3) The protection of S.139 does not apply to proceedings against the Secretary of State or against a Health Authority.

How extensive is the protection now provide by $\mathbf{S . 1 3 9}$ and can the continued existence of this discriminatory measure between general patients and mentally disordered patients be considered justified?

\section{A. Width of the protection provided}

1. Meaning of any act purporting to be done in pursuance of this Act or any regulations or rules made under this Act.

This phrase in S139(1) has not been changed from S.141 of the 1959 Act and was considered by the court in the case of Poutney v. Griffiths. The facts were that a patient at Broadmoor Hospital alleged that he had been assaulted by a male nurse. His case was that on visiting day, when the time had come for visitors to leave, he was bidding farewell to members of his family when the male nurse approached and said, "Come on you", and without more ado punched him on the shoulder and almost caused him to lose his balance. The male nurse's account was that he had called out three times "Somerset House", of which the patient was an inmate, and had collected up all the patients except him. He asked him to come along, but the patient walked past, whereupon the nurse put up his hand to stop him. When he did this, the patient "went up and fell heavily on his heels", although the nurse had merely touched the patient's shoulders. In the subsequent magistrates' hearing the Justice of the Peace found the nurse guilty of common assault and he was given a conditional discharge for two years. However, the patient had not sought the leave of the High Court to bring the case, nor was there any mention of S.141 of the Mental Health Act 1959 made in the Magistrates' Court. The High Court quashed the conviction on the grounds that the criminal proceedings were a nullity since leave of the High Court had not been obtained. The High Court held that the nurse was entitled to the protection of S.141. "He was exercising his function to control the patients when he was calling on them to say goodbye to their families and make their way back to their quarter". On any view the incident happened when the nurse was on duty and when he was purportedly exercising his functions as a nurse. Accordingly he could claim the protection of the section (Lord Widgery C. J. 1975 I All ER 900 at 903).

In the House of Lords the barrister for the patient asserted that $\mathrm{S} .141$ should be interpreted narrowly, only covering those specific functions expressly referred to in the Section. If a wider interpretation were given to the Section by implying other functions, then the effect would be to whittle down, by implied terms, the subject's recourse to the courts for the determination of his right-contrary to a fundamental rule recognised by the Courts.

His argument was however rejected unanimously by the House of Lords who dismissed the appeal against the Divisional Court's decision. They reaffirmed Lord Widgery's view that "where a male nurse is on duty and exercising his functions of controlling the patients in the hospital, acts done in pursuance of such control or purportedly in pursuance of such control are acts within the scope of S.141 and are thus protected by the Section".

Yet one could argue that any action done in relation to a detained patient is caught by the Section and leave would therefore be required before proceedings could be instituted. Yet informal patients would not be faced with the same barrier unless they were taking proceedings in relation to an action taken under S.5(2) (72 hour detention of informal patient), S.5(4) (use of holding power by a prescribed nurse) or $\mathbf{S . 5 7}$ (brain surgery or hormonal implants). On the other hand the informal patient is in hospital by virtue of S.131:

Nothing in this Act shall be construed as preventing a patient who requires treatment for mental disorder from being admitted to any hospital or mental nursing home in pursuance of arrangements made in that behalf and with out any application order, or direction rendering him liable to be detained under this Act, or from remaining 
in any hospital or mental nursing home in pursuance of such arrangements after he has ceased to be so liable to be detained.

and it could be argued that an informal patient is in hospital by virtue of an act purporting to be done in pursuance of S.131. However that is probably too wide an interpretation of S.139. This was the view taken by the Court in the case of R v. Moonsami Runighian (Crim L.R 1977 p. 361).

In this case the defendant was a male nurse in a hospital to which the Mental Health Act 1959 applied. One count against him alleged that he had assaulted an informal patient, who was severely subnormal. The patient had not obtained the leave of the High Court before instituting the prosecution. The defence moved to quash the count on the ground that S.141(2) of the Mental Health Act 1959 required the leave of the High Court to be obtained before such proceedings were brought and that in the absence of that leave the proceedings were accordingly a nullity. It was held that S.141 did not apply to proceedings instituted by informal patients because acts done to such persons were not done in pursuance of the Mental Health Act on any of the relevant rules or enactments set out in Section 141 . Section 5 (the predecessor of S.131) did not mean that acts done to informal patients after their admission by private arrangement under that section were done in pursuance of the Mental Health Act. Such acts were accordingly outside the scope of S.141 and the leave of the High Court was not required. The defendant was eventually acquitted on all counts.

However this was only a decision of the Crown Court and the application of S.139 to actions in relation to informal patients must still remain in doubt.

\section{An order for judicial review}

If a patient is not seeking to bring civil and criminal proceedings against an employee, but rather asking the court to review the legality of a particular action, i.e. seeking an order from the High Court for certiorari, then this action is not covered by $\mathrm{S.139}$ and there is no requirement for the applicant to establish that the act was done in bad faith or without reasonable care.

In the case of $\mathbf{R} \mathbf{v}$. Hallstrom and another ex parte $W$. (1985, 3, All ER, 775) the patient had been suffering from schizophrenia for 10 years. Her illness had certain socially disruptive aspects including aggression and setting fire to things. However her ability to function normally was helped by regular administration of slow release injections. She was living outside the hospital on medication which she then refused to take and denied that she had ever been ill. To ensure that she took medication an order was made under S.3 of the 1983 Act and then the following day leave of absence was granted under $S .17$ subject to the necessary condition to ensure she received medication. On an application by the patient to the Mental Health Review Tribunal, the MHRT considered that the patient should not be discharged, but in giving its reasons for the decision stated that it accepts that it is not now appropriate for the patient to receive medical treatment in a hospital ..., but it is both appropriate and desirable that she should be liable to be detained in hospital for medical treatment in order that steps may be taken by the RMO under the existing Authority to admit the patient to hospital without delay should she relapse quickly and require urgent medical treatment in a hospital.

The Court of Appeal held that S.139 did not cover proceedings for judicial review and she should be able to challenge the application which led to her admission to hospital. She did not suggest that the doctors acted in bad faith or without reasonable care, nor was she interested in seeking to claim damages against the doctors. A judicial review involves an inquiry into decisions-in this case whether there has been a plain excess of jurisdiction or not. The proceedings are not an action against the decision maker (Ackner L. J., p.780).

In the subsequent substantive hearing of the case $R \mathbf{v}$. Hallstrom and Another exp. W. 19852 W.L.R. 883 the Queen's Bench Division granted her application holding that Section 3 did not authorise a nominal period of detention for a time when no necessary treatment was required to be given, and since the doctors did not consider that treatment as an in-patient was appropriate, their recommendations for her admission for treatment overnight purportedly in accordance with Section 3 were unlawful.

The significance of the Court of Appeal decision that an application for judicial review is not caught by S.139 provides greater protection for the patient since he can challenge the legality of the application for admission or any other action under the Act and the regulation without proving bad faith or lack of reasonable care. This is particularly important since the Court of Appeal held in this same case (and this was one of their grounds for reaching the above conclusion) an application to a Mental Health Review Tribunal cannot be used to challenge the initial admission.

\section{B. In bad faith or without reasonable care}

What guidance have the courts given on the interpretation of these words?

In Re Buxton and another v. Jayne and others (1960 2 All ER 688), a case based on the legislation prior to the Mental Health Act 1959, the Court of Appeal held that the doctor's failure to satisfy himself that Mrs B was of unsound mind was a substantial ground for contending that he had acted without reasonable care. In this case there were troubles in the patient's family and she had made herself ill over the whole affair. She was seen by her doctor and given a nerve tonic and sedative tablets. A few days later, after a visit from the husband, the GP decided she should be sent into hospital for observation and treatment and got in touch with the authorised officer, Mr Jayne, for him to visit Mrs Buxton. That morning she had had an upset with her son and, according to Mr Jayne's evidence, her husband appeared to be holding her down in the chair and she was shouting and screaming to such an extent that normal conversation was impossible. The GP arrived and Mrs Buxton 
refused to sign the form for voluntary admission and was then removed by ambulance to hospital. She remained there for three days under the emergency provision of S.20 of the Lunacy Act 1890 . She was then discharged because the magistrate refused to make a reception order.

The absence of any mention in Mr Jayne's affidavit that he believed her to be of unsound mind, which was essential to justify a compulsory order, was to the Court of Appeal substantial grounds for allowing the application to proceed to trial.

In the earlier case of Richardson v. London County Council 19572 All ER 330, the Court of Appeal held that public authorities, who had acted without jurisdiction and placed on an enactment a construction which, if erroneous, was yet one that the enactment was reasonably capable of bearing, had acted in good faith and in a reasonable manner and were protected by legislation comparable to that of S.139. Whether they acted without reasonable care was to be considered having regard to the state of the law as it was at the time of their acts. In this case a mentally defective patient had been confined since 1925 and on his release in 1954 brought an action against those who had secured his detention. The County Council had taken him to a place of safety on the basis that he was 'found neglected'. These words were given a different meaning in a later case ( $R \mathbf{v}$. Board of Control, Ex p. Rutty 1956 I All ER 769) but the interpretation given to them was considered reasonable at that time. In fact as Lord Parker said- - "but for Ex p. Rutty and the law expounded there, these proceedings would never have been heard of".

This decision is in keeping with the standard of care applied in civil courts to determine if there has been negligence: the fact that practice and procedures have changed since the incident complained of does not necessarily imply negligence by the defendant. Provided the defendant was acting according to the accepted professional practice at the time there is no negligence and, even where he has not followed the approved practice, provided such a departure was reasonable and justifiable, again there is no negligence.

\section{c. Test to be applied in seeking leave of Court}

The omission of the requirement, "if there is substantial grounds" in S.139(2) gives rise to the question what must an applicant now establish in order to succeed in obtaining leave to proceed with his application?

Under S.141(2) the courts required the applicant to satisfy the judge that there was substantial ground for the contention that the proposed defendant had acted in bad faith or without reasonable care; it was not enough for the applicant to show that there was a conflict of evidence. The judge had to take into account all the evidence, including that adduced on behalf of the defendant, and to consider the matter on the basis of the strength of the evidence and the inherent probabilities of the matter. This test was laid down in Carter v. Commissioner of Police for Metropolis 19752 All ER 33. In this case a woman was taken to a police station and then a mental hospital under S.136 after a neighbourhood dispute. The Court of Appeal upheld the judge's decision that there were no substantial grounds for thinking there was want of reasonable care or bad faith.

Any suggestion of rigged evidence by the police was dismissed by Lawton L. J. at p. 40.

If the doctor joined the conspiracy then it might have been possible to put the applicant into custody under the powers given to doctors by the Mental Health Act 1959. But for what purpose? Nobody wants a woman who is not mentally ill to be in a mental hospital. The pressure on beds is now so great, as we all know, that the difficulty is to get anybody into a mental hospital. The improbabilities in this case are so great that the story cannot possibly be accepted as showing substantial ground for allowing a claim to be put forward for damages for false imprisonment.

In a subsequent case Kynaston v. Secretary of State for Home Affairs, 1981 C.A. p. 281, the Court of Appeal decided that there were no substantial grounds for the appellant's contention that the Secretary of State had acted without reasonable care: there were good and sound reasons why the Home Secretary declined to consent to an absolute discharge.

To what extent has the absence of the phrase 'substantial grounds' benefited the applicant? In Winch v. Jones 19853 All ER 97, the Court of Appeal had to decide the new test to determine whether leave should be given to bring proceedings. Parker L. J. said that it was the purpose of S.139 of the 1983 Act that the protection afforded to those purporting to act under the Mental Health Acts should be reduced. He saw the purpose as being "to prevent them from being exposed to or harassed by clearly hopeless actions." The judge's task in hearing the application is not to conduct a trial on affidavits; "the purpose is to see whether the evidence before him adds up to the answer: if this allegation were tried out, there is no realistic possibility that the case might succeed."

Sir John Donaldson rejected a test of has the applicant established a prima facie case "because this leads inevitably to a full dress rehearsal of the claim and the defence, as indeed occurred in this case, and that is quite inappropriate in my judgement to an application for leave to begin proceedings. Furthermore, as in the case of judicial review, at the stage at which leave is sought, the applicant may well have reasonable suspicions that there has been a failure to exercise reasonable care, but be quite unable to put forward a prima facie case in the absence of discovery." He saw S.139 as giving a defendant greater protection than that provided under RSC Ord $18 \mathrm{r} 19$. That rule gives to the defendant the right to apply to have the case against him struck out, whereas in S.139 it is the applicant who has to seek leave to proceed.

The section is intended to strike a balance between the legitimate interests of the applicant to be allowed, at his own risk, as to costs, to seek the adjudication of the courts on any claim which is not frivolous, vexatious, or an abuse of the process and the equally legitimate interests of the respondent to such an application not to be subjected to the undoubted exceptional risk of being treated under the Mental Health Acts. In striking such a balance, the issue 
is not whether the applicant has established a prima facie case or even whether there is a serious issue to be tried, although that comes close to it. The issue is whether, on the materials immediately available to the court, which of course can include material furnished by the proposed defendant, the applicant's complaint appears to be such that it deserves the full investigation which will be possible if the intended applicant is allowed to proceed (p. 102).

\section{Conclusions}

What, then, are the conclusions?

(1) S.139 gives certain protection in relation to any act performed in relation to a detained patient, so that the patient will have to obtain the leave of the court to proceed against an individual. No leave is required to pursue an action against a Health Authority or the Secretary of State.

(2) S.139 gives certain protection in relation to any act performed in relation to an informal patient under the Act.

(3) $95 \%$ of all patients are informal and they probably do not therefore have to seek the leave of the Court to proceed unless they are complaining about an action taken under the Act or statutory regulations.

(4) Patients who are being treated for physical disorders do not have to seek the leave of the Court to institute legal proceedings.
(5) No leave is required to bring an action for an order of certiorari.

(6) In seeking leave to proceed the applicant does not have to show substantial ground or even a prima facie case of bad faith or want of reasonable care.

(7) Want of reasonable care and bad faith are comparable to the failure to follow the approved standard of care used in the civil courts to determine the existence of negligence.

(8) Any defendant to a civil action can seek an Order under RSC 18 r 19 to have the case struck out.

(9) A defendant in a criminal case can have his case rejected by the Examining Justices when committal proceedings are held.

My conclusion is that in view of the protection that the defendant already enjoys, the weakening of S.141(2) and the small number of patients covered by $S .139(2)$, there is no longer any justification for the applicant to face this hurdle and $S .139(2)$ could be repealed without undue hardship to the staff.

Leave is not required under S.139 to bring an action against the Health Authority and possibly the time has now come when it should no longer be required to bring an action against an individual.

\section{A Tribute to Sir Martin Roth}

On 19 June, 1987 the North-East Division of the College combined with the Newcastle University Department of Psychiatry to pay a conference tribute to Professor Sir Martin Roth as he approaches his 70th birthday. The Teaching Centre of the Freeman Hospital, Newcastle was an appropriate setting for such an event for Sir Martin spent 21 years as Professor of Psychiatry in Newcastle and the large attendance indicated the affection he still evokes there 10 years after his departure to Cambridge. Several generations of former colleagues spanning the past 30 years were present and the eminent positions they had reached in psychiatry, both at home and overseas, demonstrated what an intellectual power-house this small provincial department became under Sir Martin's direction.

The scientific programme encompassed many of Sir Martin's particular interests, including The Classification of Anxiety Disorders (Professor Sydney Brandon), Depression in Childhood (Professor Issy Kolvin), Criminal Behaviour in the Elderly (Professor Steve Hucker), The Normal Aged (Dr Klaus Bergmann) and Clinico-Pathological Correlates of Dementia (Dr Garry Blessed). In a witty and erudite contribution Professor David Shaw, Dean of the Newcastle Medical School, himself a Professor of Neurology, reminded us that Sir Martin had begun his career in neurology and quoted with approval from his early neurological publications in which can be discerned the nucleus of many of his subsequent preoccupations.
As a prelude to Sir Martin's own presentation, three brief vignettes on pre-Newcastle Days (Professor David Kay), Newcastle Experiences (Dr Kurt Schapira) and The Cambridge Contribution (Dr Chris Mountjoy) reviewed Sir Martin's career in a not too solemn fashion. Sir Martin then enthralled the audience with a typical Rothian polemic, ostensibly about DSM-III but covering almost the whole of psychiatry, including the latest molecular findings in Alzheimer's disease.

The conference ended with a tremendous ovation as $\mathrm{Dr}$ Sasi Mahapatra, Chairman of the North-East Division, presented a memento from members of the Division to Sir Martin. There was, however, more to come as later that evening over 100 people attended a banquet in honour of Sir Martin and Lady Roth at which the fund of humorous anecdotes so deftly delivered by Kurt Schapira in his toast was only exceeded by Sir Martin's own inimitable performance. It was the potent brew of nostalgia, humour, warmth and intellectual brilliance, rather than the excellent wine, that sent us homeward with a feeling of intoxication.

Sir Martin Roth is a phenomenon of British psychiatry and after a day devoted to his phenomenology it is pleasing to report that he shows no sign of flagging and is likely to be still going strong on his 80 th birthday.

KENNETH DAVISON 